Vegetalika. 2018. 7(1): 39-51

\title{
Konsep Perencanaan Taman Museum Kars Indonesia Wonogiri, Jawa Tengah Berdasarkan Potensi Tanaman Lokal
}

\section{Plan Concept of Museum Kars Indonesia Park Wonogiri, Central Java Based on the Local Plants Potential}

\author{
Maharsadi Mahfud Amarulaziz ${ }^{1)}$, Siti Nurul Rofiqo Irwan ${ }^{2 *}$, Rohlan Rogomulyo ${ }^{2)}$ \\ 1)Program Studi Agronomi, Fakultas Pertanian, Universitas Gadjah Mada \\ 2)Departemen Budidaya Pertanian, Fakultas Pertanian, Universitas Gadjah Mada \\ *) Penulis untuk korespodensi E-mail: rofiqoirwan@ugm.ac.id
}

\begin{abstract}
This study aimed to inventory and identify local plants around Museum Kars Indonesia and to provides the planning concept of the park based on the utilization of local plants. The research was conducted by survey method with purposive sampling and in-depth interview technique. Interviews were done with some informants who were considered to have sufficient knowledge about land characteristics around Museum Kars Indonesia in order to find out local plants variety and their potential in developing the landscape quality of Museum Kars Indonesia. Interviews were conducted around the museum area which physical characters resembled to the land characteristics of the Museum Kars Indonesia. The result showed that there were 47 local plants that consisted of 34 species of trees and 13 species of shrubs and bushes. At the museum Kars Indonesia Park there were 21 species of plants that consisted of 13 species of trees and 8 species of shrubs and bushes. Local plants around Museum Kars Indonesia have potential of flowers to enhance the beauty and color variations, fruit production potential that can increased the value-added of the park and the attractiveness of visitors, variations in shape, color and size of plant canopy that were can utilized to form patterns, balanced and rhythmic as well as the diversity of plants that can be produce biodiversity in terms of plants and as an animal habitat. This research was expected to be a consideration of the museum manager to improve the quality of the museum park to be better.
\end{abstract}

Keywords: Local Plant, Museum Kars Indonesia, Wonogiri, Museum Park, Central Java

\section{INTISARI}

Penelitian ini bertujuan menginventarisasi dan mengidentifikasi tanaman lokal yang berada di sekitar Museum Kars Indonesia dan memberikan konsep perencanaan taman yang berbasis pada pemanfaatan tanaman lokal. Penelitian ini dilakukan dengan metode survei menggunakan teknik pengambilan data purposive sampling dan wawancara mendalam. Wawancara dilakukan dengan narasumber yang dinilai memiliki pengetahuan yang cukup tentang kondisi lahan Museum Kars Indonesia dan kawasan disekitarnya, mengetahui jenis-jenis tanaman lokal di kawasan museum beserta potensi yang dimiliki dalam upaya pengembangan kualitas lanskap taman Museum Kars Indonesia. Wawancara dilakukan di sekitar kawasan museum yang memiliki karakter fisik lahan yang menyerupai kondisi lahan di area Taman Museum Kars Indonesia. Hasil dari penelitian ini menunjukkan pada kawasan Museum kars Indonesia terdapat 47 jenis 
Maharsadi Mahfud Amarulaziz et al., / Vegetalika. 2018. 7(1): 39-51

tanaman lokal yang terdiri dari 34 jenis pohon, dan 13 jenis perdu dan semak. Pada Taman Museum Kars Indonesia terdapat 21 jenis tanaman yang terdiri dari 13 jenis pohon dan 8 jenis perdu dan semak. Tanaman lokal di kawasan Museum Kars Indonesia memiliki potensi berupa tanaman bunga untuk meningkatkan keindahan dan variasi warna, potensi produksi buah yang dapat meningkatkan nilai tambah taman dan daya tarik pengunjung, variasi bentuk, warna dan ukuran tajuk tanaman yang dapat dimanfaatkan untuk membentuk pola tanaman yang teratur, berimbang dan berirama serta keberagaman tanaman yang dapat menghasilkan keanekaragaman hayati (Biodiversity) dari segi tanaman maupun sebagai habitat satwa. Dengan adanya penelitian ini diharapkan dapat menjadi pertimbangan pihak pengelola museum untuk meningkatkan kualitas taman museum menjadi lebih baik.

Kata Kunci: Tanaman Lokal, Museum Kars Indonesia, Wonogiri, Taman Museum, Survei

\section{PENDAHULUAN}

Kars adalah bentang alam yang terbentuk akibat pelarutan batuan karbonat. Kawasan ini umumnya memiliki karakter kering dan gersang. Kawasan kars merupakan salah satu ekosistem yang bersifat rentan terhadap kerusakan lingkungan. Keberadaan vegetasi di kawasan kars berperan dalam menjaga kelestarian ekosistem yang terbentuk secara alami pada wilayah dengan topografi yang unik tersebut. Kemampuan perakaran tanaman dalam menembus celah sempit bebatuan menjadikan proses karstifikasi terus berlanjut sehingga dapat menjadi penunjang konservasi kawasan kars. Tanaman yang tumbuh di kawasan kars memiliki daya adaptasi yang tinggi, hal ini dapat dijelaskan karena tanaman yang berkembang pada wilayah ini dituntut untuk dapat bertahan hidup pada lahan yang miskin unsur hara. Disamping itu, karakter batuan kars yang berongga menjadikan ketersediaan air yang diperlukan untuk pertumbuhan tanaman menjadi sangat terbatas karena aliran air baik itu yang berada dipermukaan maupun yang berada di zona perakaran akan segera masuk melalui celah-celah batuan tersebut (Anonim, 2011)

Tanaman yang tumbuh di kawasan kars merupakan tanaman yang unik dan khas. Sundarapandian dan Swamy (2000), menjelaskan tentang keragaman vegetasi dalam hal struktur dan komposisi yang terdapat di suatu wilayah pada prinsipnya merupakan cerminan dari hasil interaksi antara berbagai faktor lingkungan dan dapat berubah akibat faktor aktivitas manusia (antropogenic). Seiring perkembangan peradaban manusia, seringkali nilai keunikan tanaman lokal kars diabaikan dan dengan mudah keberadaannya digantikan dengan jenis-jenis tanaman baru yang oleh manusia dirasa memiliki nilai ekonomi yang lebih besar. Apabila hal tersebut terus berlanjut maka eksistensi tanaman lokal sebagai salah satu ragam kekayaan jenis tanaman di Indonesia akan semakin berkurang. Tentunya hal ini sangat tidak diinginkan, padahal tidak dapat 
Maharsadi Mahfud Amarulaziz et al., / Vegetalika. 2018. 7(1): 39-51

dipungkiri bahwa tanaman lokal di kawasan kars berperan penting dalam konservasi sumber daya alam dan keanekaragaman hayati yang ada di kawasan kars. Tanaman lokal selain berfungsi sebagai sumber sandang, pangan dan papan juga mencerminkan karakter, etos kerja, dan kebudayaan masyarakatnya yang harus beradaptasi dengan kondisi lahan yang terbatas untuk dapat bertahan hidup. Kajian terhadap tanaman lokal penting untuk dilakukan sebagai salah satu bentuk upaya yang dapat dilakukan untuk menjaga kelestarian tanaman lokal. Melalui kajian tanaman lokal keunggulan tanaman dan juga kemampuan adaptasi dengan lingkungan akan diketahui secara lebih luas, sehingga akan diketahui potensi tanaman yang lebih mendalam dan lebih besar dari sekedar nilai jual tanaman itu sendiri. Melalui kajian tanaman lokal akan membuka wawasan umum mengenai pemanfataan tanaman lokal secara lebih baik sehingga akan mendorong pengembangan budidaya tanaman lokal di kalangan masyarakat secara luas.

Hingga saat ini, kondisi Taman Museum Kars Indonesia yang merupakan salah satu destinasi wisata penting di Kabupaten Wonogiri masih belum terkelola dengan baik. Untuk itu, perlu adanya perencanaan dan perbaikan yang dilakukan terhadap desain taman agar fungsi rekreasi dari museum ini menjadi maksimal dengan harapan dapat meningkatkan daya tarik pengunjung. Menurut Fabos (1985), Dengan perencanaan yang tepat, pengembangan suatu wilayah akan berfungsi optimal sesuai dengan setiap potensi lokal yang dimiliki.Penelitian ini diharapkan dapat menjadi pertimbangan pihak pengelola museum untuk meningkatkan kondisi museum menjadi lebih baik.

\section{BAHAN DAN METODE}

Bahan yang digunakan dalam penelitian ini peta Museum Kars Indonesia, Peta lokasi survei dan daftar pertanyaan wawancara. Alat yang digunakan dalam penelitian ini adalah roll meter, kamera, perangkat lunak Corel draw, Garden Planner dan Auto Cad. Penelitian ini dilakukan dengan metode survei dengan teknik purposive sampling.

Penelitian ini dilakukan melalui wawancara dengan narasumber yang dinilai memiliki pengetahuan yang cukup tentang kondisi lahan di Taman Museum Kars Indonesia untuk mengetahui jenis-jenis tanaman lokal yang ada dikawasan museum beserta potensi yang dimiliki dalam upaya pengembangan kualitas lanskap taman Museum Kars Indonesia. Wawancara dilakukan di sekitar museum yang memiliki karakter fisik lahan yang menyerupai kondisi lahan di taman Museum Kars Indonesia. Hasil wawancara dianalisis dengan rumus persentase dan ditampilkan dalam bentuk diagram lingkaran. 


\section{HASIL DAN PEMBAHASAN}

Museum Kars Indonesia berada di Desa Gebangharjo, Kecamatan Pracimantoro Kabupaten Wonogiri. Museum Kars berada di dataran rendah pada kisaran ketinggian antara 200-300 mdpl. Menurut Climate-data.org (2016), kabupaten Wonogiri termasuk iklim tipe tropis Am yang memiliki curah hujan yang cukup berdasarkanklasifikasi iklim Koppen-Geiger. Temperaturudara minimum-maksimum pada wilayah ini berada pada kisaran $19^{\circ}-32^{\circ} \mathrm{C}$ dengan suhu rerata tahunan pada kisaran $25,1^{\circ} \mathrm{C}$. Curah hujan di Kabupaten Wonogiri rata-rata berkisar antara 1.557-2.476 mm/tahun dengan jumlah hari hujan antara 107-153 hari/tahun.

Berdasarkan hasil inventarisasi tanaman lokal disekitar Museum Kars Indonesia diperoleh 47 jenis tanaman lokal yang terdiri dari 34 jenis pohon, dan 13 jenis perdu dan semak. Jenis tanaman pohon penghasil buah lebih banyak diminati (17 jenis dari total 47 jenis tanaman) untuk dikembangkan terutama di lingkungan pekarangan hal ini karena tanaman buah memiliki fungsi tanaman yang lebih lengkap yaitu dapat dimanfaatkan sebagai penghias, peneduh, juga dapat memproduksi buah yang dapat dinikmati hasilnya. Tanaman buah yang mudah dijumpai dikawasan kars diantaranya mangga (Mangifera indica L.), jeruk besar (Citrus maxima Merr.), sawo (Manilkara zapota (L.) P. Royen), dan nangka (Artocarpus heterophyllus Lamk.). Tanaman buah yang di budidayakan di wilayah ini umumnya mampu berbuah setidaknya sekali dalam setahun. Pada kawasan kars yang berada diluar pekarangan umumnya didominasi oleh jenis tanaman pohon penghasil kayu seperti jati (Tectona grandis L.f.), mahoni (Swietenia mahogani (L.) Jacq.), dan akasia (Acacia auriculiformis A. Cunn. ex Benth.) yang banyak diminati untuk bahan bangunan karena dinilai memiliki kualitas kayu yang sangat baik. Ketiga jenis pohon penghasil kayu tersebut umumnya dipilih karena sangat cocok untuk dikembangkan pada wilayah kars karena memiliki kemampuan tumbuh yang baik di wilayah tersebut.

Pada Taman Museum Kars Indonesia terdapat 21 jenis tanaman yang terdiri dari 13 jenis pohon dan 8 jenis perdu dan semak. Dari beberapa jenis pohon yang ditanam di taman museum, jenis tanaman pohon yang mendominasi adalah tanaman kelengkeng (Dimocarpus longan Lour.) dengan jumlah sebanyak 19 pohon. Tanaman kelengkeng yang ditanam di taman museum lebih berfungsi sebagai pengontrol iklim mikro yaitu untuk mengatur suhu agar lebih sejuk karena kondisi dilapangan cenderung terik terutama pada siang hari di musim kemarau. 


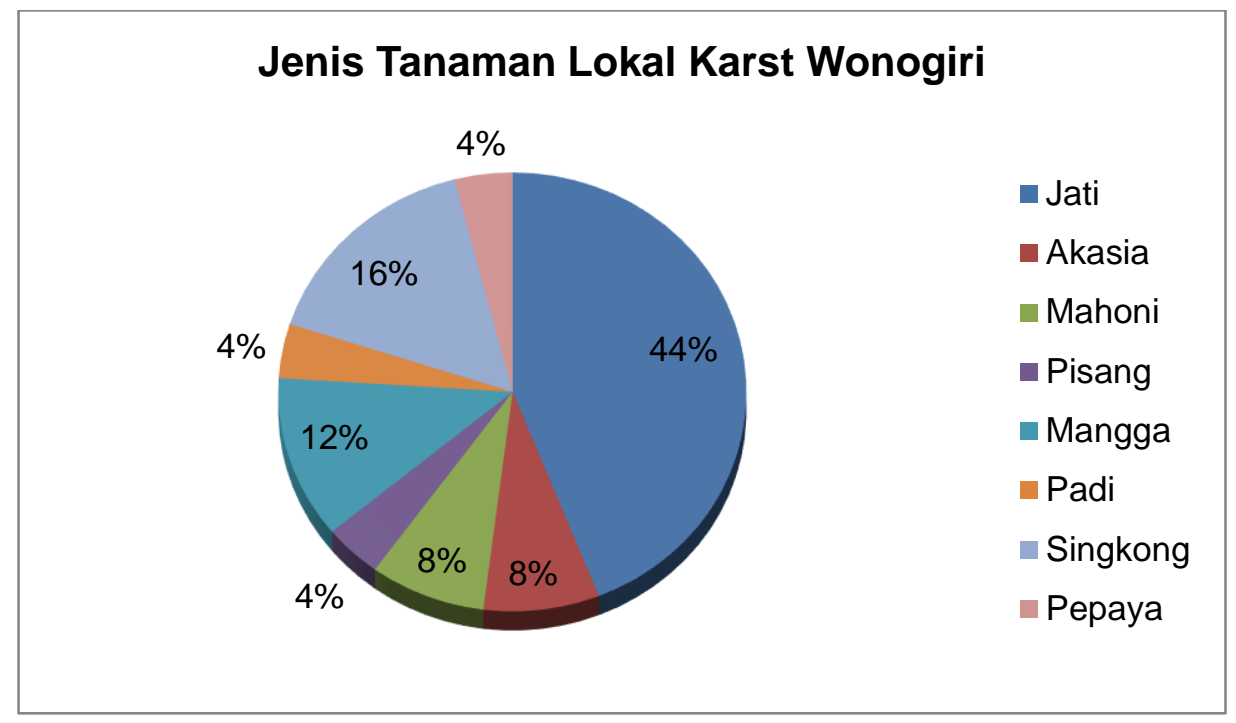

Gambar 1. Diagram Lingkaran Jenis Tanaman Lokal Karst Di Wonogiri

Gambar 1 menunjukkan prosentase jenis tanaman lokal di kawasan Museum kars Indonesia, dengan prosentase tertinggi adalah tanaman jati (Tectona grandis L.f.) sebesar $44 \%$. Tanaman jati dibudidayakan secara luas oleh masyarakat pada daerah yang kurang cocok untuk digunakan sebagai lahan pertanian. Maraknya budidaya tanaman jati umumnya didasari karena nilai ekonominya sangat tinggi sebagai bahan bangunan karena kayu jati terkenal kuat dan memiliki kualitas yang sangat baik. Dari gambar diagram lingkaran diatas tanaman singkong (Manihot esculenta Crantz.) dan mangga (Mangifera indica L.) secara berurutan menempati posisi kedua dan ketiga yang memiliki presentase terbesar, hal ini dapat dijelaskan karena tanaman singkong merupakan tanaman pangan lokal yang banyak dibudidayakan di Wonogiri bahkan tanaman ini merupakan tanaman yang sudah menjadi ikon/identitas daerah Kabupaten Wonogiri. Tanaman ini banyak dibudidayakan pada daerah-daerah pertanian yang memiliki kesuburan tanah rendah. Tanaman singkong umumnya ditanam sebagai alternatif tanaman pangan selain padi. Produk singkong biasanya diolah menjadi salah satu makanan lokal khas yaitu nasi tiwul (Sego Thiwul). Kemudian, untuk tanaman mangga umumnya dibudidayakan sebagai tanaman penghasil buah di pekarangan. Alasan utama yang menjadikan tanaman mangga banyak dibudidayakan adalah perawatannya sangat mudah dan potensi produksinya cukup melimpah. 


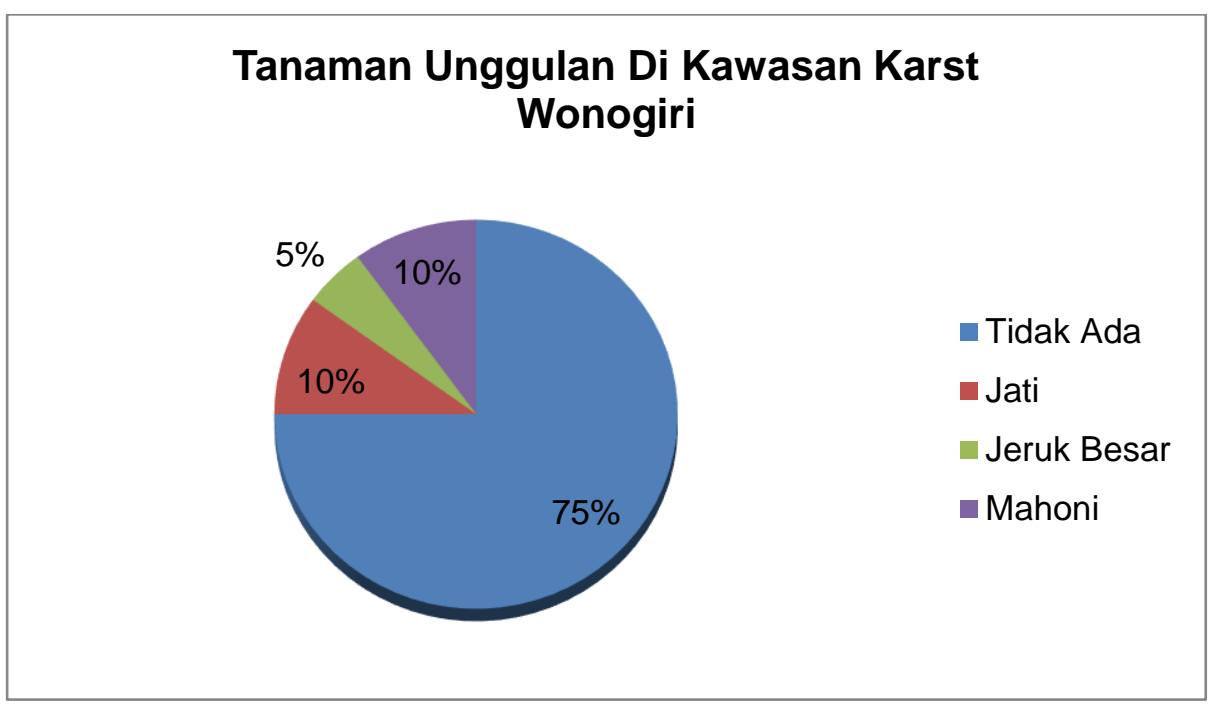

Gambar 2. Tanaman Unggulan di Kawasan Karst

Produk tanaman dikawasan museum kars indonesia meskipun sudah cukup berkembang namun hingga saat ini menurut sebagian besar narasumber, 75\%, menyatakan pada wilayah ini belum ada/ tidak ada suatu jenis tanaman yang menjadi unggulan di wilayah tersebut (Gambar 2). Tanaman dikawasan kars belum ada yang menonjol secara kuantitas produksi yang dapat meningkatkan peningkatan pendapatan di masyrakat. Hal ini dapat terjadi karena dua hal yaitu faktor lingkungan yang terbatas dan belum maksimal dalam upaya intensifikasinya. Menurut Kepala bidang hortikultura Dinas Pertanian Kabupaten Wonogiri, pada wilayah kars yang tanahnya sudah berkembang berpotensi untuk dikembangkan tanaman hortikultura yang beragam. Pada wilayah sekitaran museum, sudah ada berbagai macam produk hortikultura golongan buah yang telah di upayakan dan dapat berproduksi diantaranya jeruk besar (Citrus maxima Merr.), nangka (Artocarpus heterphyllus Lamk.), mangga (Mangifera indica L.), sawo (Manilkara zapota (L.) P. Royen), srikaya (Annona muricata L.), kelengkeng (Dimocarpus longan Lour.) dsb. Diantara beragam jenis buah yang di uji tersebut menunjukkan mangga dan jeruk besar paling berpotensi untuk dikembangkan karena memiliki kemampuan produksi yang cukup baik dan relatif mudah kegiatan pemeliharaannya, serta dari segi kebutuhan airnya sudah dapat tercukupi dari curah hujan yang ada. 
Maharsadi Mahfud Amarulaziz et al., / Vegetalika. 2018. 7(1): 39-51

Tabel 1. Potensi tanaman lokal di kawasan Museum Kars Indonesia

\begin{tabular}{|c|c|c|c|c|c|c|}
\hline No & Nama Lokal & Nama ilmiah & Bunga & Buah & Tajuk & Biodiversity \\
\hline 1 & Sirsak & Annona muricata L. & - & + & - & + \\
\hline 2 & Srikaya & Annona squamosa L. & - & + & - & + \\
\hline 3 & Sawo & $\begin{array}{l}\text { Manilkara zapota (L.) P. } \\
\text { Royen }\end{array}$ & - & + & - & + \\
\hline 4 & Mangga & Mangifera indica L. & - & + & - & + \\
\hline 5 & Pete & Parkia speciosa Hassk. & - & + & - & - \\
\hline 6 & Rambutan & Nephelium lappaceum L. & - & + & - & - \\
\hline 7 & Nangka & $\begin{array}{l}\text { Artocarpus heterophyllus } \\
\text { Lamk. }\end{array}$ & - & + & - & + \\
\hline 8 & Alpukat & Persea americana Mill. & - & + & - & + \\
\hline 9 & Kelengkeng & Dimocarpus longan Lour. & - & + & - & + \\
\hline 10 & JerukBesar & Citrus maxima Merr. & - & + & - & + \\
\hline 11 & Pepaya & Carica Papaya L. & - & + & - & + \\
\hline 12 & $\begin{array}{l}\text { Glodogan } \\
\text { Tiang }\end{array}$ & Polyalthia longifolia Sonn. & - & - & + & - \\
\hline 13 & Jambu air & $\begin{array}{l}\text { Syzygium aquaeum (Burm. } \\
\text { F.) Alston }\end{array}$ & - & + & - & + \\
\hline 14 & Jambu batu & Psidium guajava L. & - & + & - & + \\
\hline 15 & Kedondong & Spondias dulcis L. & - & + & - & + \\
\hline 16 & Belimbing & Averrhoa carambola L. & - & + & - & + \\
\hline 17 & Matoa & $\begin{array}{l}\text { Ponnetia pinniata J.R. \& } \\
\text { G.Forst }\end{array}$ & - & + & - & + \\
\hline 18 & Bulu & Ficus balabacensis Quisumb. & - & - & + & + \\
\hline 19 & Ipik & Ficus retusa L. & - & - & + & + \\
\hline 20 & Beringin & Ficus benjamina L. & - & - & + & + \\
\hline 21 & Tanjung & Mimusops elengi L. & - & - & + & - \\
\hline 22 & Saputangan & $\begin{array}{l}\text { Maniltoa grandiflora (A.Gray) } \\
\text { Scheff. }\end{array}$ & - & - & + & - \\
\hline 23 & Tabebuya & $\begin{array}{l}\text { Tabebuia impetiginosa(Mart. } \\
\text { Ex DC.) Standl. }\end{array}$ & + & - & + & - \\
\hline 24 & Preh & Ficus ribes Reinw. & - & - & + & + \\
\hline 25 & Spatodea & $\begin{array}{l}\text { Spathodea campanulata P. } \\
\text { Beauv. }\end{array}$ & + & - & - & - \\
\hline 26 & $\begin{array}{l}\text { Dadap } \\
\text { merah }\end{array}$ & Erythrina crista-galli L. & + & - & + & - \\
\hline 27 & Jati & Tectona grandis L.f. & - & - & - & + \\
\hline 28 & Akasia & $\begin{array}{l}\text { Acacia auriculiformis A. Cunn. } \\
\text { ex Benth. }\end{array}$ & + & - & - & - \\
\hline 29 & Jabon & Anthocepalus cadamba Miq. & - & - & - & + \\
\hline 30 & Trembesi & Samanea saman (Jacq.) & + & - & - & + \\
\hline 31 & Sengon & $\begin{array}{l}\text { Albizia chinensis (Osbeck.) } \\
\text { Merr. }\end{array}$ & - & - & - & + \\
\hline 32 & Eboni & Diospyroscelebica Bakh. f. & - & - & - & + \\
\hline 33 & Gaharu & Aquilaria malaccensis Lamk. & - & - & - & + \\
\hline 34 & Cendana & Santalum album L. & - & - & - & + \\
\hline
\end{tabular}


Maharsadi Mahfud Amarulaziz et al., / Vegetalika. 2018. 7(1): 39-51

Lanjutan Tabel 1. Potensi Tanaman Lokal Di Kawasan Museum Kars Indonesia

\begin{tabular}{|c|c|c|c|c|c|c|}
\hline No & $\begin{array}{l}\text { Nama } \\
\text { Lokal }\end{array}$ & Nama ilmiah & $\begin{array}{c}\mathrm{Bu} \\
\mathrm{nga}\end{array}$ & Buah & Tajuk & $\begin{array}{l}\text { Biodiv } \\
\text { ersity }\end{array}$ \\
\hline 35 & Kunyit & Curcuma longa L. & - & - & - & + \\
\hline 36 & Jahe & Zingiber officinale Rosc. & - & - & - & + \\
\hline 37 & Euphorbia & Euphorbia milii Desmoul. & + & - & - & - \\
\hline 38 & Kencur & Kaempferia galanga L. & - & - & - & + \\
\hline 39 & $\begin{array}{l}\text { Temu } \\
\text { lawak }\end{array}$ & Curcuma zanthorrhiza Roxb. & - & - & - & + \\
\hline 40 & Binahong & $\begin{array}{l}\text { Anredacordi folia (Ten.) } \\
\text { Steenis }\end{array}$ & - & - & - & + \\
\hline 41 & Sereh & $\begin{array}{l}\text { Cymbopogon citratus (DC.) } \\
\text { Stapf }\end{array}$ & - & - & - & + \\
\hline 42 & $\begin{array}{l}\text { Sirih } \\
\text { merah }\end{array}$ & Piper ornatum N. E. Br. & - & - & - & + \\
\hline 43 & Lengkuas & Alpinia galanga (L.) Willd. & - & - & - & + \\
\hline 44 & $\begin{array}{l}\text { Temu } \\
\text { ireng }\end{array}$ & Curcuma aeruginosa Roxb. & - & - & - & + \\
\hline 45 & $\begin{array}{l}\text { Cabe } \\
\text { puyang }\end{array}$ & Piper retrofractum Vahl. & - & - & - & + \\
\hline 46 & $\begin{array}{l}\text { Lidah } \\
\text { mertua }\end{array}$ & Sansevierra trifasciata Prain. & - & - & + & - \\
\hline 47 & Zig-zag & $\begin{array}{l}\text { Pedilanthus tithymaloides L. } \\
\text { Poit }\end{array}$ & - & - & + & - \\
\hline
\end{tabular}

Keterangan : (+) memiliki potensi; (-) tidak memiliki potensi

Dari tabel 1 dapat dilihat bahwa kawasan kars memiliki beraneka ragam jenis tanaman yang berpotensi sebagai penghasil buah diantaranya sirsak (Annona muricata L.), srikaya (Annona squamosaL.), sawo(Manilkara zapota (L.) P. Royen), nangka (Artocarpus heterphyllus Lamk.), kelengkeng(Dimocarpus longan Lour.), alpukat (Persea americanaMill.), jeruk besar (Citrus maxima Merr.), dsb. Hal tersebut menunjukkan bahwa kawasan kars memiliki potensi produk buah-buahan yang sangat beragam. Namun dari tabel diatas masih sedikit dijumpai tanaman yang memiliki potensi berupa bunga. Tercatat hanya ada tabebuya (Tabebuia impetiginosa (Mart. Ex DC.) Standl.), spatodea (Spathodea campanulata P.Beauv.), dadap merah (Erythrina cristagalli L.), dan euphorbia (Euphorbia milii Desmoul.). Seluruh jenis tanaman yang berpotensi memiliki keunggulan organ tanaman berupa bunga diatas lebih cenderung untung dimanfaatkan sebagai hiasan untuk meningkatkan variasi warna.

Tanaman di kawasan kars yang memiliki potensi berupa tajuk memiliki keragaman yang cukup baik, ada yang memiliki kekuatan dari segi bentuk berupa kerucut seperti glodogan tiang (Polyalthia longifolia Sonn.), volume tajuk besar adalah kelompok beringin (Ficus benjamina L.), buluh (Ficus balabacensis Quisumb.), dan ipik (Ficus retusa L.). Dari segi keindahahan warna adalah dadap merah (Erythrina crista- 
Maharsadi Mahfud Amarulaziz et al., / Vegetalika. 2018. 7(1): 39-51

galli L.), saputangan (Maniltoa grandiflora (A.Gray) Scheff.) dan lidah mertua (Sansevierra trifasciata Prain.). Tanaman lokal di kawasan kars juga berpotensi meningkatkan keragaman hayati dari segi tanaman itu sendiri maupun dengan kemampuannya menyediakan lingkungan hidup bagi satwa diantaranya seperti tanaman bulu (Ficus balabacensis Quisumb.), ipik (Ficus retusa L.) dan beringin (Ficus benjamina $L$,) yang rindang dapat bermanfaat sebagai media bersarang burung maupun binatang lain yang hidup dengan peneduh. Hadirnya tanaman buah seperti pepaya (Carica papaya L.), sawo (Manilkara zapota (L.) P. Royen), sirsak (Annona muricata L.), srikaya (Annona squamosa L.) dapat berpotensi menjadi sumber pangan satwa apabila lingkungan tersebut menjadi komponen dari habitatnya.

Untuk mempermudah proses perencanaan taman museum, hal hal yang perlu dilakukan adalah mencari sumber daya lokal yang memiliki kemampuan untuk meningkatkan daya tarik museum. Salah satu bentuk pemanfaatan sumberdaya lokal adalah pemanfaatan tanaman lokal sebagai komponen utama dalam merancang taman museum. Tujuan digunakannya tanaman lokal untuk menguatkan karakter wilayah kars yang sangat spesifik sehingga memerlukan penekanan pada pemanfaatan vegetasi spesifik kars dan mempermudah proses pemeliharaan taman.

Tanaman lokal yang ada di kawasan kars memiliki kemampuan yang sudah turun temurun teruji dapat beradaptasi dengan berbagai komponen lingkungan yang ada di wilayah kars. Pemanfaatan tanaman lokal juga berguna untuk merepresentasikan identitas daerah setempat dan museum sebagai bangunan/monumen yang berfungsi untuk mengenalkan karakter wilayah yang ada di kawasan kars khususnya Kawasan Geopark Gunung Sewu.

Untuk mendukung fungsi dari museum kars maka dalam perencanaan taman museum kars harus menggunakan konsep yang baik agar seluruh fungsi yang diinginkan dapat tercapai secara bersamaan. Konsep yang perlu ditekankan terkait permasalahan yang ada di taman museum kars adalah konsep vegetasi, adapun prosesnya terbagi dalam tiga tahap, yaitu:

\section{Perencanaan ruang}

Untuk mempermudah proses pencanaan maka perlu dilakukan pengelompokan wilayah di area taman museum sesuai dengan bentuk aktivitas yang ada di dalamnya. Adapun area di taman museum dapat dikelompokkan menjadi 5 wilayah yaitu: area pintu masuk (welcome area), area parkir, area ibadah (mushola), area bangunan utama museum, dan rest area. 


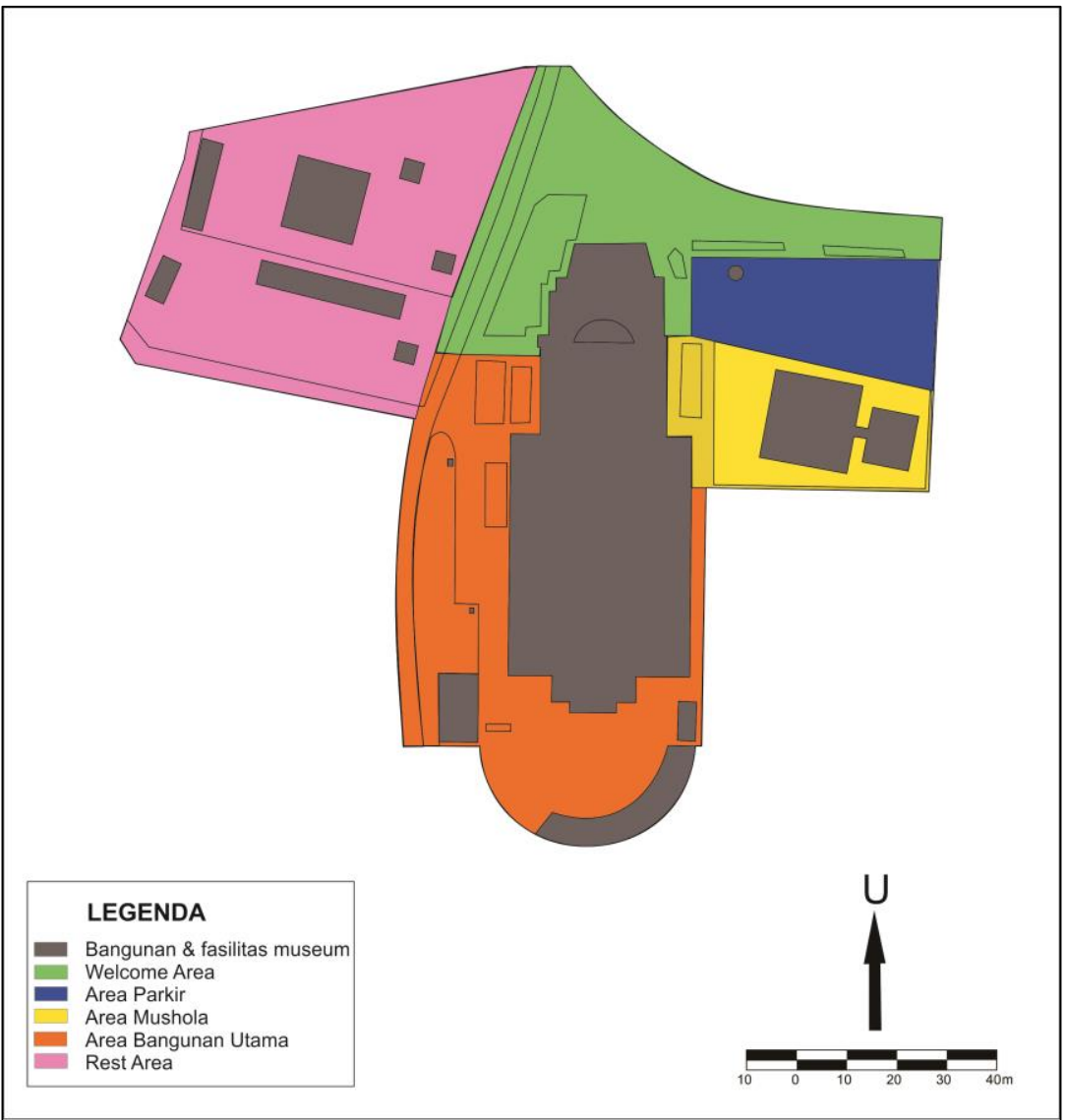

Gambar 3. Zona Taman Museum Kars Indonesia

2. Seleksi tanaman alternatif

Dalam penentuan konsep rancangan taman yang perlu diperhatikan adalah bentuk aktivitas yang ada pada area tersebut, sebab salah satu tujuan utama pembuatan konsep taman diantaranya harus dapat mendukung aktivitas yang berlangsung dalam area tersebut menjadi semakin kondusif dan estetis (Vandyke,1990). Untuk mencapai tujuan tersebut maka diperlukan penyesuaian jenis tanaman yang akan digunakan sesuai fungsi masing-masing wilayah yang telah ditentukan Untuk menentukan jenis vegetasi yang direkomendasikan untuk dikembangkan di taman Musem Kars Indonesia dapat dilakukan sesuai dengan kriteria pada Tabel 2.

Tabel 2. Kriteria tanaman alternatif Taman Museum Kars Indonesia

\begin{tabular}{|l|l|l|l|l|l|}
\hline No & Zona & $\begin{array}{l}\text { Fungsi } \\
\text { area }\end{array}$ & $\begin{array}{l}\text { Kriteria } \\
\text { tanaman }\end{array}$ & Alternatif Tanaman lokal & $\begin{array}{l}\text { Alternatif Tanaman } \\
\text { Pendukung }\end{array}$ \\
\hline 1 & Pintu & $\begin{array}{l}\text { Menerima } \\
\text { kunjungan }\end{array}$ & $\begin{array}{l}\text { Indah/unik, } \\
\text { tidak terlalu } \\
\text { besar }\end{array}$ & $\begin{array}{l}\text { Tabebuya (Tabebuia } \\
\text { impetiginosa Mart. Ex. } \\
\text { DC. Standl.), } \\
\text { Dacang Hias (Arachis } \\
\text { Dadap merah (Erythrina } \\
\text { crista-galli L.), } \\
\text { saputangan (Maniltoa } \\
\text { grandiflora (A. Grey) } \\
\text { Scheff.) }\end{array}$ & $\begin{array}{l}\text { Gregory) } \\
\text { Iris kuning (Neomarica } \\
\text { longifolia L.) }\end{array}$ \\
& & & & \\
\hline
\end{tabular}


Maharsadi Mahfud Amarulaziz et al., / Vegetalika. 2018. 7(1): 39-51

\begin{tabular}{|c|c|c|c|c|c|}
\hline 2 & $\begin{array}{l}\text { Area } \\
\text { Parkir }\end{array}$ & $\begin{array}{l}\text { Parkir } \\
\text { kendaraan }\end{array}$ & $\begin{array}{l}\text { Peneduh, } \\
\text { kokoh, } \\
\text { pohon } \\
\text { besar } \\
\text { (nonbuah) }\end{array}$ & $\begin{array}{l}\text { Bulu (Ficus balabacensis } \\
\text { Quisumb.), Ipik(Ficus } \\
\text { retusa L.), tanjung } \\
\text { (Mimusops elengi L.), } \\
\text { sapu tangan (Maniltoa } \\
\text { grandiflora (A. Grey) } \\
\text { Scheff.) }\end{array}$ & $\begin{array}{l}\text { Iris Kuning (Neomarica } \\
\text { longifolia L.) }\end{array}$ \\
\hline 3 & Mushola & $\begin{array}{l}\text { Sholat, } \\
\text { istirahat }\end{array}$ & Peneduh & $\begin{array}{l}\text { Dadap merah (Erythrina } \\
\text { crista-galli L.), } \\
\text { Kelengkeng (Dimocarpus } \\
\text { longan Lour.) }\end{array}$ & $\begin{array}{l}\text { Bunga Sepatu (Hibiscus } \\
\text { rosa-sinensis), Palem Raja } \\
\text { (Roystonia regia (Kunth.) } \\
\text { O.F. Cook.) }\end{array}$ \\
\hline 4 & $\begin{array}{l}\text { Bangunan } \\
\text { utama }\end{array}$ & $\begin{array}{l}\text { Area } \\
\text { sirkulasi } \\
\text { kunjungan }\end{array}$ & $\begin{array}{l}\text { Indah, } \\
\text { Koleksi, } \\
\text { Identitas } \\
\text { daerah }\end{array}$ & $\begin{array}{l}\text { Dadap merah (Erythrina } \\
\text { crista-galli L.), tabebuya } \\
\text { (Tabebuia impetiginosa } \\
\text { (Mart. Ex. DC.)Standl.), } \\
\text { Spatodea (Spathodea } \\
\text { campanulata P.Beauv.) }\end{array}$ & $\begin{array}{l}\text { Jambu mete (Anacardium } \\
\text { oecidentale L.), } \\
\text { Soka ( Ixxora connica L.) } \\
\text { Prasman (Ayapana } \\
\text { triplinervis (M.Vahl) R.King } \\
\text { \& H.Robinson) Ruellia } \\
\text { (Ruellia angustifolia C. } \\
\text { Wright) }\end{array}$ \\
\hline 5 & Rest area & $\begin{array}{l}\text { Istirahat, } \\
\text { makan }\end{array}$ & $\begin{array}{l}\text { Peneduh, } \\
\text { pengarah, } \\
\text { Estetika, } \\
\text { produksi }\end{array}$ & $\begin{array}{l}\text { Trembesi (Samanea } \\
\text { saman (Jacq.)), Jeruk } \\
\text { Besar (Citrus maxima } \\
\text { Merr.), sirsak (Annona } \\
\text { muricata), srikaya } \\
\text { (Annona squamosa L.), } \\
\text { mangga (Mangifera Indica } \\
\text { L.) }\end{array}$ & $\begin{array}{l}\text { Iris kuning (Neomarica } \\
\text { longifoia L.) }\end{array}$ \\
\hline
\end{tabular}

3. Konsep perencanaan desain taman

Tanaman lokal yang telah dipilih dan memenuhi kriteria yang ditetapkan kemudian disusun dalam sebuah konsep desain rencana penanaman yang dapat dilihat pada Gambar 4. Pembuatan konsep perencanaan adalah didasarkan pada fungsi tanaman dan fungsi ruang di taman museum kars (Tabel 2). Pada pengembangan di setiap zonasi taman, ditata tanaman berdasarkan jenis pohon, semak dan penutup tanah, yaitu tanaman local dan tanaman pendukung. Beberapa pohon buah dan tanaman hias digunakan dalam perencanaan berupa alternatif perencanaan. Konsep perencanaan ini masih dapat dikembangkan pada beberapa alternatif perencanaan taman, dengan menggunakan tanaman lokal dan tanaman pendukung, Gambar 4 merupakan salah satu alternatiif perencanan taman yang dapat diterapkan untuk Taman Museum Kars Indonesia. 
Maharsadi Mahfud Amarulaziz et al., / Vegetalika. 2018. 7(1): 39-51

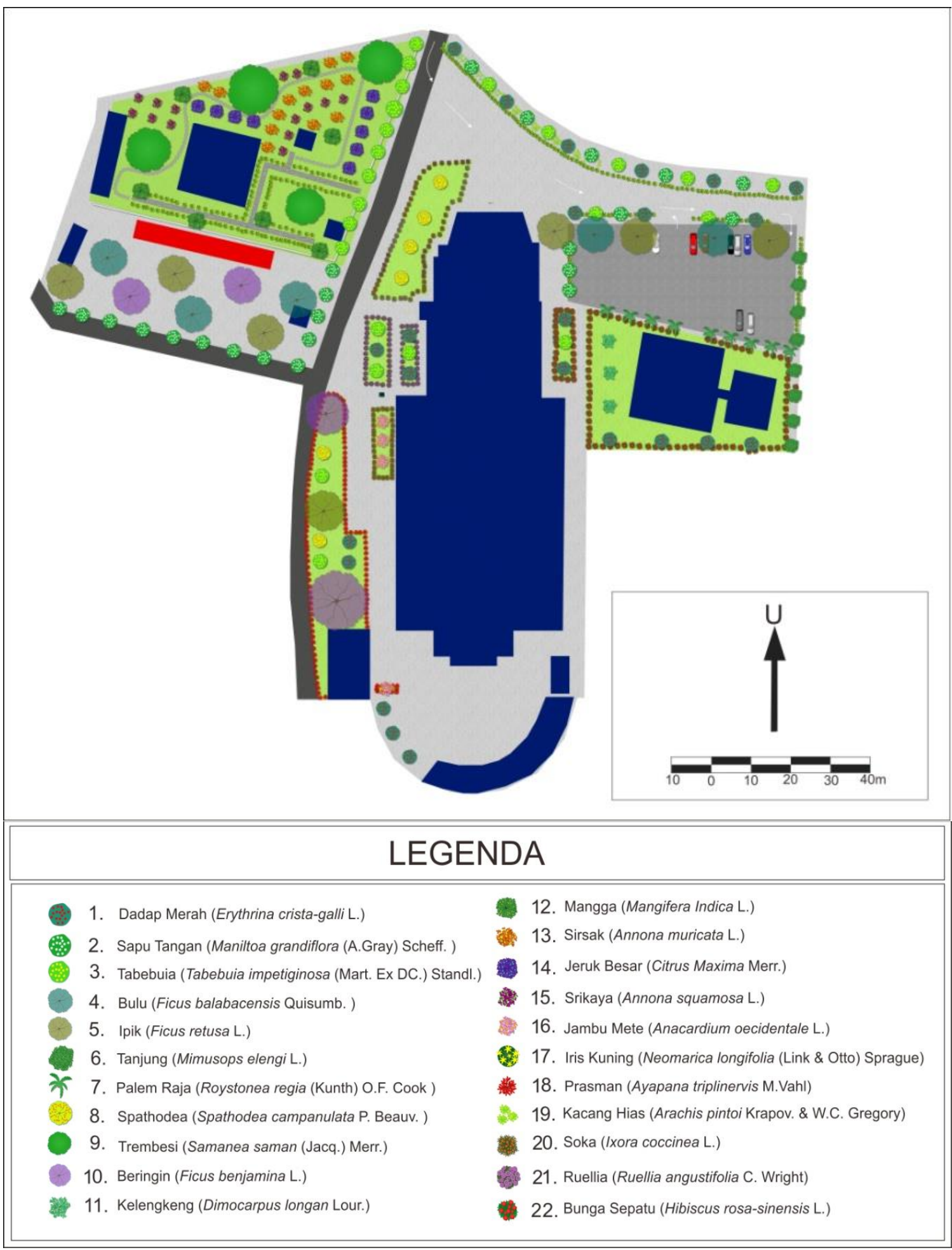

Gambar 4. Konsep Desain Taman Museum Kars Indonesia 
Maharsadi Mahfud Amarulaziz et al., / Vegetalika. 2018. 7(1): 39-51

\section{KESIMPULAN}

1. Pada kawasan Museum kars Indonesia terdapat 47 jenis tanaman lokal yang terdiri dari 34 jenis pohon, dan 13 jenis perdu dan semak. Pada Taman Museum Kars Indonesia terdapat 21 jenis tanaman yang terdiri dari 13 jenis pohon dan 8 jenis perdu dan semak

2. Tanaman lokal di kawasan Museum Kars Indonesia memiliki potensi berupa bunga untuk meningkatkan keindahan dan variasi warna, potensi produksi buah yang dapat meningkatkan nilai tambah taman dan daya tarik pengunjung, variasi bentuk, warna dan ukuran tajuk tanaman yang dapat dimanfaatkan untuk membentuk pola tanaman yang teratur, berimbang dan berirama serta keberagaman tanaman yang dapat menghasilkan keanekaragaman hayati (Biodiversity) dari segi tanaman maupun sebagai habitat satwa.

\section{DAFTAR PUSTAKA}

Anonim. 2011. Museum Kars Indonesia. <http://www.geomagz.geologi.esdm.go.id/museum-karst-indonesia/>.Diakses tanggal 21 Mei 2016.

Climate-data. 2016. Iklim di Kabupaten Wonogiri. <http://www.climate-data.org/ilimkabupaten-wonogiri/>. Diakses tanggal 18 November 2016.

Fabos, J.G.1985. Land-Use Planning From Global to Local Challenge. Chapman \& Hall, New York.

Sundarapandian, S.M. and P.S. Swamy. 2000. Forest Ecosystem Structure and Composition Along an Altitudinal Gradient in the Western Ghats, South India. Journal of Tropical Forest Science 12 (1) :104-123.

Vandyke, S. 1990. From Line to Design. Van Nostrand Reinhold Co. New York. 